\title{
Roles of dysregulated Notch pathway and small DNA tumor viruses in cancer initiation and progression
}

\author{
Anthony G. Clementz ${ }^{1}$, Paola Rizzo ${ }^{2}$, Fernanda Martini², Mauro Tognon ${ }^{2}$ \\ ${ }^{\prime}$ Department of Chemistry, College of Health and Sciences, DePaul University, Chicago, IL 60614, USA. \\ ${ }^{2}$ Department of Morphology, Surgery and Experimental Medicine, Section of Pathology, Oncology and Experimental Biology, Laboratories of Cell \\ Biology and Molecular Genetics, School of Medicine, University of Ferrara, 44121 Ferrara, Italy.
}

Correspondence to: Dr. Mauro Tognon, Department of Morphology, Surgery and Experimental Medicine, Section of Pathology, Oncology and Experimental Biology, Laboratories of Cell Biology and Molecular Genetics, School of Medicine, University of Ferrara, 44121 Ferrara, Italy.

E-mail: tgm@unife.it

\section{A B S T R A C T}

Notch pathway is a major determinant of cell fate, and research within the last 30 years has shown dysfunctions within this pathway in the majority of solid tumors and leukemias. The molecular mechanisms causing aberrant expression of Notch in cancer are still partially known. Mesotheliomas, breast, and cervical cancers are among the cancer types for which the dysregulation of Notch has been reported together with the association of simian virus 40 (SV40) or human papilloma virus (HPV) infections. In mesotheliomas and cervical cancer, there is clear evidence that these viruses cause and rely on dysregulation of the Notch pathway to promote and sustain cell transformation. The existence of a relationship in tumors between DNA viruses and Notch could have an impact on cancer therapy by implementing Notch inhibition to interfere with the growth of SV40- and HPV-positive cancers. In addition, since Notch links innate and acquired immunity and plays a key role in the regulation of the anti-viral response, targeting Notch in the presence of oncogenic viruses infections may help prevent the onset and progression of cancers associated with the exposure to these viruses.

Key words: Cancer; human papilloma virus; Notch; pathway; simian virus 40

\section{INTRODUCTION}

Notch has been identified as a critical pathway aberrantly expressed in many types of solid tumors and leukemias. Dysregulation of Notch signaling is a result of many factors including interactions with viral proteins. In this short review, we took in consideration significant articles dealing with the dysregulation of the Notch pathway and/ or presence of oncogenic viruses, mainly simian virus 40 (SV40) and human papilloma viruses (HPVs), in cancer. Indeed, the proteins encoded by Notch pathway genes and the viral oncoproteins of SV40 and HPV were found in some models of study, interconnected in the cell transformation in vitro and tumor initiation and progression in vivo.

\section{BASICS OF NOTCH SIGNALING}

Beginning in the early 20th century, the discovery of a new

\begin{tabular}{|l|l|}
\hline \multicolumn{3}{|c|}{ Access this article online } \\
\hline Quick Response Code: & Website: \\
& www.jcmtjournal.com \\
\hline
\end{tabular}

Type 1 transmembrane receptor came after the identification of a specific mutation in Drosophila melanogaster, which formed a Notch on the wing of the fly. This discovery led to the naming of "Notch" to the mutated gene. ${ }^{[1]}$ In Drosophila, the Notch receptor was found to encode a $300 \mathrm{kDa}$ single-pass transmembrane receptor. Later, Notch-like molecules were identified from Caenorhabditis elegans (LIN-12) to humans, which are highly conserved and play pivotal roles in development, stem cell renewal, and differentiation in postnatal tissues. ${ }^{[2]}$ In mammalians, there are four Notch Type I transmembrane receptors (Notch 1, 2, 3, and 4) and five known ligands (deltalike 1, 3, and 4 and Jagged 1, 2). Notch signaling relies on cell-cell contact to initiate its eventual signaling activation. ${ }^{[3]}$ To be primed for mature Notch signaling activation, the protein is processed first in the trans-Golgi apparatus by furin-like convertase creating a heterodimer, which is shuttled to the cellular membrane and held

This is an open access article distributed under the terms of the Creative Commons Attribution-NonCommercial-ShareAlike 3.0 License, which allows others to remix, tweak, and build upon the work non-commercially, as long as the author is credited and the new creations are licensed under the identical terms.

For reprints contact: service@oaepublish.com

How to cite this article: Clementz AG, Rizzo P, Martini F, Tognon M. Roles of dysregulated Notch pathway and small DNA tumor viruses in cancer initiation and progression. J Cancer Metastasis Treat 2016;2:11-23.

Received: 15-05-2015; Accepted: 26-11-2015 
together by $\mathrm{Ca}^{2+}$ cations. The mature receptor is available to interact with its ligand, which subsequently stimulates through conformational changes a second proteolytic cleavage by tumor necrosis factor- $\alpha$ converting enzyme or a disintegrin and metalloprotease $(10 / 17) .{ }^{[4]}$ This in turn results in shedding of the extra-cellular portion of Notch, which through receptor-mediated endocytosis, propagates signaling events in neighboring cells. The final cleavage occurs within the membrane through an associated aspartyl protease known as the $\gamma$-secretase complex composed of presenilin, nicastrin, APH 1 and PEN2. ${ }^{[5]}$ Intra-cellular Notch cleaved protein translocates to the nucleus where it binds with the transcription factor recombining binding protein-Jk or C-promoter-binding factor 1/suppressor of hairless/Lag1 (CSL $)^{[6]}$ and, after displacing co-repressors and recruiting co-activators such as p300, histone acetyl transferases, and mastermind-like protein 1 (MAML1), it activates downstream pathways [Figure 1]. ${ }^{[7]}$ The "canonical" Notch signaling is known to activate genes coding for transcriptional factors such as those belonging to the hairy/enhancer of split (Hes1-5), the hairy-related (Hrt), and the Hes1-5-Hrt with YRPW motif (Hey) families involved in inhibiting neuronal differentiation. ${ }^{[8]}$ The "canonical" Notch pathway is a major determinant of cell proliferation and survival through the activation of genes controlling cell cycle progression such as cyclin $\mathrm{D}^{[9]}$ and genes belonging to the anti-apoptotic pathway nuclear factor kappa-light-chain-enhancer of activated B-cells (NF- $\kappa \mathrm{B}) \cdot{ }^{[10,11]}$ Notch activation can also be attained in a "non-canonical" fashion initiated by a non-canonical ligand or may not require cleavage of the Notch receptor. ${ }^{[1]}$ Among suggested mechanism of "non-canonical" Notch signaling are interactions of Notch with non-CSL transcription factors, such as $\beta$-catenin, ${ }^{[12]}$ hypoxia-inducible factor- $1 \alpha, \mathrm{NF}-\kappa \mathrm{B},{ }^{[13]}$ and estrogen receptor $\alpha(\mathrm{ER} \alpha) \cdot{ }^{[14]}$ Anti-apoptotic activity independent of canonical functions has been associated with active Notch1, which signals via the kinase AKT to prevent the loss of mitochondrial function and consequent nuclear damage and requires mitochondrial remodeling proteins mitofusins- 1 and $2 \cdot{ }^{[15]}$ Notch activity is finely regulated by interactions with other key proteins and pathways, among them $\mathrm{p} 53,{ }^{[16]} \mathrm{ER} \alpha,{ }^{[17,18]}$ the epidermal growth factor B2 $(\text { ErbB-2 })^{[19]}$ and the vascular endothelial growth factor receptors (VEGFRs), ${ }^{[20]}$ the Wingless (Wnt ${ }^{[21,22]}$ and Hedgehog ${ }^{[23]}$ signaling pathways. Recent genome-scale studies in D. melanogaster have revealed an even more complex network of genes that can affect Notch activity ${ }^{[24]}$ consistent with decades of work showing that the highly conserved Notch pathway is extremely complex, and the output of its activation or its inhibition will result in differentiation, proliferation or increased survival based on the existing cellular context.

\section{NOTCH SIGNALING PATHWAY IN TUMORS}

Many reports have been published on the role of the Notch pathway in the development of the cardiovascular system, ${ }^{[25,26]}$ in regulation of stem cells functions such as survival of cardiac progenitor cells, ${ }^{[27]}$ the differentiation

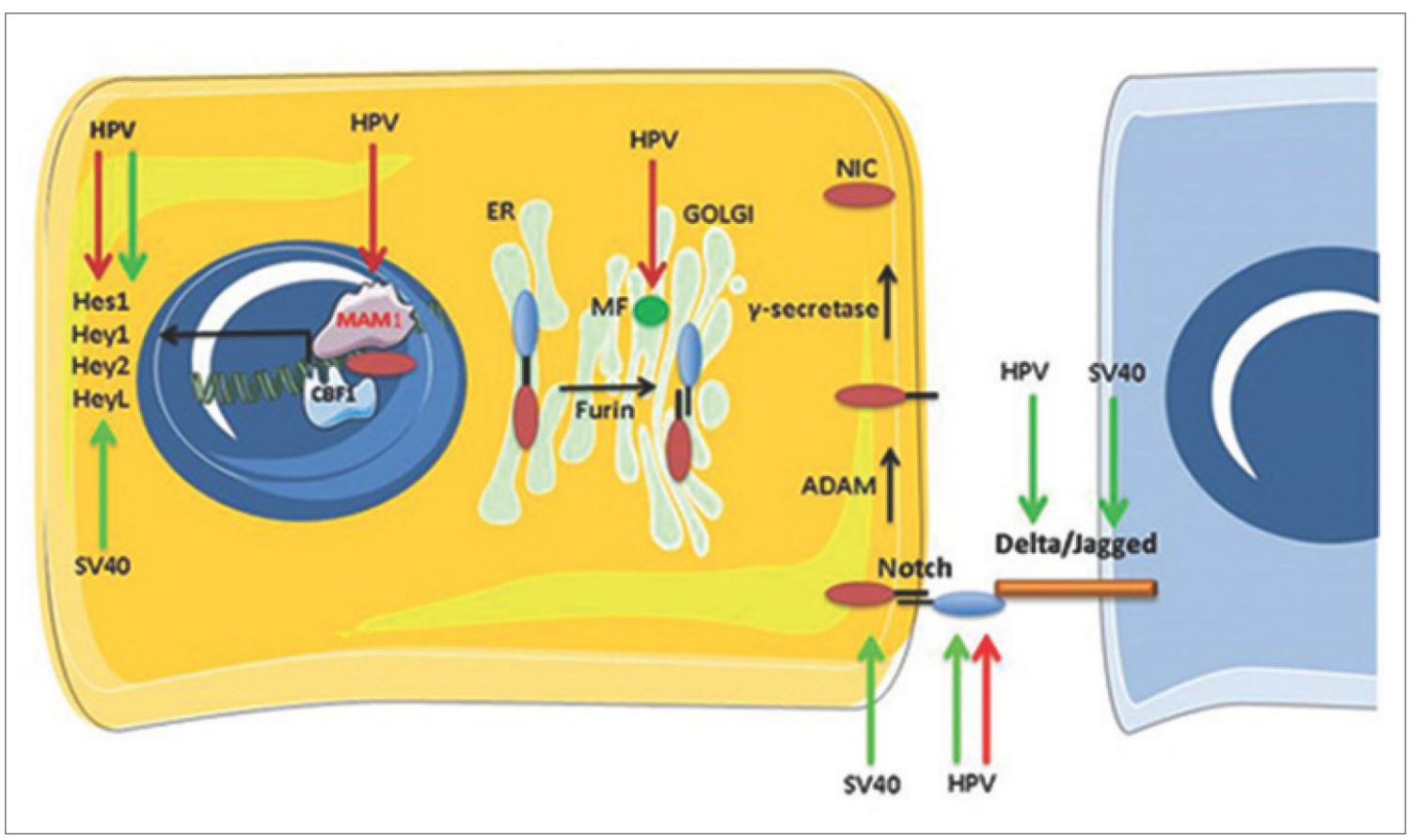

Figure 1: Schematic representation of the events leading to Notch signaling activation and the steps of this process affected by the oncogenic viruses simian virus 40 and human papillomavirus. Notch precursor is cleaved in the Golgi apparatus by a furin-like convertase and then exposed on the cell membrane. Notch ligands Delta/Jagged bind Notch extra-cellular subunit. This causes a disintegrin and metalloprotease to clip the extra-cellular portion of Notch transmembrane generating an intermediate, cleaved by $\gamma$-secretase which releases active Notch. Active Notch enters the nucleus, where it causes the dissociation of silencing mediator of retinoic acid and thyroid hormone receptor corepressor complex from C-promoter-binding factor 1/suppressor of hairless/Lag1, and recruits mastermind-like 1 coactivator complex, resulting in transcription of target genes. Simian virus 40 induces upregulation of the Notch pathway, whereas conflicting reports exist on the modulation of Notch by human papillomavirus (green arrow indicates up-regulation, red arrow indicates down-regulation or inhibitory binding) 
of insulin-secreting pancreatic cells ${ }^{[28]}$ of inner ear hair cells, ${ }^{[29]}$ and intestinal crypt and goblet cells. ${ }^{[30]}$ Accordingly, the important role of the Notch pathway for normal tissues development has been proven by the identification of Notch mutations in human inherited diseases. Indeed, Notch alterations have been detected in: (1) Cerebral autosomal dominant arteriopathy, with subcortical infarcts and leukoencephalopathy (a heritable arteriopathy that leads to damaged small blood vessels and irreversible dementia); (2) spondylocostal dysostosis (characterized by abnormal development of bones in the spine and ribs); (3) Alagille syndrome affecting the liver, heart, kidney, and other systems of the body; ${ }^{[31]}$ (4) congenital heart diseases. ${ }^{[32]}$ Similarly, in the last decade, it has been demonstrated that the Notch signaling pathway contributes to the regulation of the immune system by playing a role in multiple lineage decisions of developing lymphoid and myeloid cells. ${ }^{[33]}$ Recent work has shown that Notch, through macrophage-dependent delta-like ligand 1 and 4 signaling, is critical in providing an antiviral response by linking innate and acquired immunity during influenza ${ }^{[34]}$ and dengue ${ }^{[35]}$ viral infections.

Notch has emerged as a potent oncogene when it was first shown that a subset of T-cell acute lymphoblastic leukemias (T-ALL) contained achromosomal translocation, $t(7 ; 9)$, leading to abnormal expression of the Notch1 intracellular domain, ${ }^{[36]}$ which was later shown to be able to cause T-cell neoplasm in mice. ${ }^{[37]}$ Later studies confirmed the existence of Notch1 mutation in $60 \%$ of human T-ALL. ${ }^{[38]}$ In T-cell neoplasms, Notch1 represses p53, ${ }^{[38]}$ induces c-myc, ${ }^{[39]}$ and inhibits phosphatase and tensin homolog, a downregulator of the phosphatidylinositol 3 kinase (PI3K)-AKT pathway involved in promoting cancer cell survival. ${ }^{[40]}$ Recent work has shed light on the role of Notch in T-ALL showing that in these tumors aberrant Notch activity counteracts the tumor suppression function of the transcription factor IKZF1 (IKAROS). ${ }^{[41]}$

The major role played by Notch in breast cancer is also well established. Reports of an involvement of Notch in mammary gland development and neoplasia came from the observation of the Notch4/int3 gene as a common provirus integration site in mammary tumors of mice infected with mouse mammary tumor virus (MMTV), ${ }^{[42]}$ followed by the report that transgenic female mice carrying Notch 1 and 3 activating mutations (caused by the insertion of the MMTV) developed mammary gland tumors. $^{[43]}$ Notch has been found activated in $\mathrm{ER} \alpha$ positive-, negative-, triple negative-breast cancer cell lines and breast cancer cell lines overexpressing the oncogene Her2/neu.$^{[18,19,44]}$ Dysregulation of Notch has been shown in human breast cancer biopsies ${ }^{[45-47]}$ in which overexpression of Notch1 and one of its ligands, Jagged1 has been linked to poor prognosis and overall diminished survival. ${ }^{[48,49]}$ Of interest, Notch2 overexpression was instead associated with increased survival in breast cancer patients, ${ }^{[49]}$ suggesting a role for Notch 2 as a tumor suppressor gene in these cancers. In agreement with this observation, active Notch2 induces reduction in tumor take and increased apoptosis in human MDA-MB-231 (ER $\alpha$, Her2 negative cell line) xenograft tumor growth. ${ }^{[50]}$ The Notch pathway is a major determinant of breast cancer stem cells survival, and Notch activation in these cells has been linked to resistance to tamoxifen. ${ }^{\left[{ }^{[1,52]}\right.}$ Consistently, Notch activation plays a role in tamoxifen resistance observed in protein kinase $\mathrm{C}-\alpha$ overexpressing estrogen-responsive breast cancers ${ }^{[53]}$ and in ErbB-2-positive breast tumors. ${ }^{[54]}$

Dysregulated expression of Notch proteins, ligands, and targets has been described in a multitude of solid tumors, including cervical, head and neck, endometrial, renal, lung, pancreatic, ovarian, prostate, esophageal, oral, hepatocellular and gastric carcinomas, osteosarcoma, mesothelioma melanoma, gliomas, medulloblastomas, and rhabdomyosarcoma. ${ }^{[8]}$ Dysregulation of Notch signaling has been reported in some hematological malignancies, other than T-ALL, including Hodgkin lymphomas, anaplastic large-cell non-Hodgkin lymphomas, acute myeloid leukemias, and B-cell chronic lymphoid leukemias multiple myeloma (for the original articles on the subject the reader is referred to). ${ }^{[8]}$

Tumor angiogenesis is crucial for cancer growth and progression. ${ }^{[55]}$ The Notch pathway promotes cancer growth not only by enhancing the survival of cancer cells and their progenitors but also by controlling tumor vascularization. Dll4/Notch1-mediated signaling modulates VEGF-A-driven angiogenesis by affecting the number of sprouts (new branches) on endothelial cells. This interplay between Dll4/Notch1/VEGFR determines the balance between the number of tip cells (leading and guiding the blood vessel sprout) and stalk cells (proliferating cells forming the vascular lumen). ${ }^{[24,56]}$ Interference with tumor angiogenesis by inhibition of Dll4-mediated signaling has been effective in blocking cancer growth in animal models. ${ }^{[57]}$ Recently, high levels of Jagged1 have also been shown to promote tumor angiogenesis by destabilizing the tip and stalk cell fates ${ }^{[58]}$ and by regulating levels of VEGFR1, 2[59] and activate Notch3/Hey1 in tumor cells thus promoting proliferation, survival, and epithelial to mesenchymal transition. ${ }^{[59]}$ Consistently, inhibition of experimental tumors growth has been obtained by blocking Jagged1-dependent Notch signaling. ${ }^{[60]}$

Notch inhibitors are currently under clinical investigation, in combination with existing therapies for the treatment of several types of cancers. ${ }^{[61]}$ Considering the role of Notch in maintaining intestinal homeostasis, patients treated with Notch inhibitors require clinical monitoring of the gastrointestinal tract. ${ }^{[62]}$ Furthermore, due to the effect of Notch in promoting angiogenesis and survival of cardiac progenitor cells, cancer patients with preexisting ischemic diseases should also be monitored for possible 
cardiotoxicity linked to the use of Notch inhibitors. ${ }^{[63]}$

The mutations causing the activation of Notch signaling have been identified for T-ALLs; ${ }^{[38]}$ however, little is known about the molecular mechanism involved in dysregulating Notch in other malignancies. Few activating mutations of the Notch pathway have been found in solid tumor patients, with most being observed in non-small cells lung ${ }^{[64]}$ and head and neck cancers. ${ }^{[65]}$ In breast and lung cancers, inactivation of Numb, a protein involved in Notch1 downregulation, has also been identified. ${ }^{[64,66]}$ Rearrangements of the Notch gene families have been found in breast cancer. ${ }^{[67]}$

\section{THE ROLE OF SMALLDNATUMOR VIRUSES IN THE PATHOGENESIS OF CANCER}

\section{SV40}

SV40 ${ }^{[68]}$ is a monkey virus, which was accidentally administered to humans, in the years 1955-1963, through contaminated poliovirus vaccines. ${ }^{[69,70]}$ However, a more recent study indicates that some oral poliovirus vaccines were contaminated with infectious SV40 in sub-sequent years. ${ }^{[71]}$ Early experiments both in vitro and in vivo classified SV40 as a transforming and oncogenic viral agent. These activities are due to SV40 large tumor antigen(Tag) and small tumor antigen (tag), which act as activated viral oncogenes. ${ }^{[69,70]}$ These studies addressed a new wave of investigations into the potential of SV40 to induce cancer in humans. To date, hundreds of molecular and epidemiologic studies aimed at investigating whether SV40 infects humans, its potential mode of transmission and its putative role in human tumors have been carried out. ${ }^{[72-74]}$

SV40 was assigned to the family of Papovaviridae, an acronym proposed by Melnick ${ }^{[75]}$ obtained by fusing the names of the 3 representative viruses papilloma, polyoma, and vacuolating agent. However, this nomenclature at present is considered obsolete. More recently, SV40 has been enclosed among polyomaviruses, together with the human polyomaviruses (HPyV), BK Polyomavirus (BKPyV), and JC polyomavirus (JCPyV). The virion is about $45 \mathrm{~nm}$, an icosahedral particle, with a density of 1.34$1.35 \mathrm{~g} / \mathrm{cm}^{3}$. The viral genome is a circular, double-stranded DNA molecule. SV40 encodes for six main viral proteins: Two early non-structural polypeptides, Tag and tag, an agnoprotein, probably involved in the assembly of viral particles and processing of late messenger RNA (mRNA) and 3 capsid proteins, VP1, VP2 and VP3. ${ }^{[76-78]}$ The early and late genes are transcribed on different DNA strands in a way that the transcription proceeds divergently from the regulatory region. This region contains the origin of DNA replication and binding sites for the transcription factors that control viral gene expression and terminates within DNA sequences containing the polyadenylation signals. Recently, a predicted late polarity pre-microRNA to the untranslated region $3^{\prime}$ of the polyadenylation cleavage site in the late pre-mRNA has also been detected. ${ }^{[79,80]}$ SV40 is phylogenetically, closely related to HPyV. There is evidence of similarity with respect to size (about $5.2 \mathrm{~Kb}$ ), genome organization, and DNA sequence. The tags of SV40, BKPyV, and JCPyV strongly cross-react with the same antisera ${ }^{[81,82]}$ while a less, strong cross-reactivity is observed in most structural antigenic determinants of the viral proteins, named VP1, 2 and 3. A genus-specific capsid antigen, located on viral peptide VP1, has been

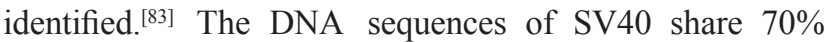
homology with BKPyV, ${ }^{[84]}$ and $69 \%$ with JCPyV ${ }^{[85]}$ The greatest homology is found in the early region coding for the Tags and tags, whereas a lower homology is detected in the regulatory region.

Transformation of rodent and human cells by SV40 is induced by the 2 oncoproteins, Tag and tag, which display multiple functions. The main activity of Tag for cell transformation ${ }^{[69]}$ and tumorigenesis is to target key cellular proteins, ${ }^{[86-88]}$ such as the tumor suppressor $\mathrm{p} 53^{[89-91]}$ and retinoblastoma protein (pRB) family proteins, inactivating their functions. ${ }^{[92-94]}$ SV40 Tag may also lead to transformation by inducing mutations to the cellular genome ${ }^{[95]}$ or numerical and structural alterations of chromosomes, ${ }^{[96,97]}$ such as gaps, breaks, dicentric and ring chromosomes, chromatid exchanges, deletions, duplications, and translocations. ${ }^{[98]}$ The principal role of the tag in transformation is to bind the catalytic $(36 \mathrm{kDa})$ and regulatory $(63 \mathrm{kDa})$ sub-units of protein phosphatase 2A (PP2A), ${ }^{[69,86]}$ inactivating their function. Moreover, tag interacts with the centrosome and blocks mitosis in human cells, ${ }^{[99]}$ suggesting that it may disrupt cell cycle progression. Recently, it has been shown that in human mammary epithelial cells tag activates PI $3 \mathrm{~K}^{[100]}$ an enzyme involved in pathways crucial for cell proliferation, and transformation through phosphorylation of the hydroxyl moiety present on the phosphatidylinositol inositol ring. Aberrant regulation of EGFR upstream from PI3K through mutations in EFGR can lead to cancer promotion in glioblastoma. ${ }^{[101,102]}$ In addition, SV40 tag can enhance transcription from E2F-activated promoters of early growth response genes. ${ }^{[103,104]}$ The process of rodent cell transformation induced by SV40 typically depends on the integration of the viral DNA into the host genome where it produces a high level of expression of the major viral oncogenic proteins, Tag, and tag. However, human cells experimentally transformed by SV40 harbor viral genomes in an episomal state in addition to integrated viral DNA. SV40 immortalized ${ }^{[105]}$ and transformed human cells ${ }^{[106-108]}$ can induce tumors when implanted subcutaneously in autologous hosts. ${ }^{[107]}$ An SV40 Tag needs cooperation of the catalytic sub-unit of telomerase and the activated c-HRas oncogene, for the complete transformation of human cells, as shown in cotransfection experiment. ${ }^{[109]}$ SV40 is highly oncogenic in rodents and when inoculated subcutaneously, intra-cerebrally, or intra-venously in newborn hamsters induces soft 
tissue sarcomas, osteosarcomas, ependymomas and choroid plexus papillomas, and neoplasms of the hematopoietic system, such as lymphocytic leukemia, histiocytic lymphomas and rarely, and B-cell lymphomas, respectively. ${ }^{[87,110-112]}$ Direct inoculation of SV40 into the pleural space induces malignant mesothelioma in $100 \%$ of the injected hamsters. ${ }^{[111]}$ The oncogenic potential of SV40 is confirmed by the generation of transgenic mice in which polyomavirus large Tag expression is regulated by the native viral early promoter enhancer. ${ }^{[13]}$ Furthermore, SV40-transgenic mice develop ependymomas and choroid plexus papillomas, as well as other neoplasms. ${ }^{[87,114-116]}$ Many reports were published on SV40 sequences detected, at high prevalence in human cancers of the same histotypes induced by this small DNA tumor virus in experimental animals, that is, lymphoproliferative disorders, mesothelioma, and bone and brain tumors. ${ }^{[72,117,118]}$ SV40 sequences were also detected at low prevalence in healthy subjects. ${ }^{[119-121]}$

Most of these studies were obtained by polymerase chain reaction techniques. More recently, investigations reported the detection at high prevalence of specific antibodies in serum samples from patients affected by malignant pleural mesothelioma, ${ }^{[122]}$ glioblastoma multiforme, ${ }^{[123]}$ osteosarcoma, ${ }^{[124]}$ ocular melanoma, ${ }^{[125]}$ and non-Hodgkin lymphoma, ${ }^{[126]}$ suggesting an association of SV40 with these human cancers. Indeed, in serum samples from normal individuals ${ }^{[127-129]}$ or patients affected by tumors, and $^{[130,131]} /$ other pathologies ${ }^{[132,133]} \quad$ unrelated to SV40, the prevalence of antibodies against SV40 is lower than that detected in human cancers found to be associated with SV40. It is worth noting that taken at all, the prevalence of SV40 sequences and the prevalence of specific antibodies against SV40 in these human tumors/normal tissues and sera, respectively, are very similar. This result indicates that SV40 is also a human virus, which infection occurs at low prevalence in normal individuals. Altogether, these data suggest that this small DNA tumor virus of monkey origin seems to be associated at high prevalence with specific human cancers. It is also possible that the immunologic data are due to the cross-reactivity with a new, still undetected, human polyomavirus closely related to SV40.

\section{HPV}

HPV infection is considered to be the main oncogenic agent for the onset of female genital tumors. ${ }^{[134]}$ HPVs are non-enveloped small DNA tumor viruses, with a double-stranded genome of approximately $8.2 \mathrm{~kb}$. HPVs are sub-divided into 2 classes such as low-risk, which are detected in mainly genital warts, and high-risk (HR), which are associated with invasive cervical cancer. HR HPV includes 15 types $(16,18,31,33,35,39,45,51$, 52, 56, 58, 59, 68, 73 and 82), whereas low-risk HPV includes 12 types $(6,11,40,42,43,44,54,61,70,72,81$ and 108). ${ }^{[135]}$ However, the oncogenic potential of HPV is mediated by the expression of the viral oncoproteins identified as E6 and E7. The role of HPV E6 and E7 oncoproteins in HPV-associated cervical carcinogenesis is mainly due to their interaction with the cellular tumor suppressor p53 and members of the pRB family, respectively. ${ }^{[136-138]}$ The mechanisms of action of HPV cause genetic instability and cell transformation resulting in cell cycle regulated escape and inhibition of apoptosishallmarks of cancer initiation and progression. ${ }^{[139]}$ Studies on the association between HPV and cervical neoplasia have indicated a strong link between these oncogenic virus types. ${ }^{[140]}$

Research demonstrates that only a fraction of HPV-positive women develops genital tumors. ${ }^{[141]}$ Indeed, the majority of patients who are infected with HPV can clear these viral agents naturally within 1 year. ${ }^{[142]}$ Persistent infection with HR HPV at a high viral load in cervical mucosa is considered the main cause of the initiation and progression of genital tumors ${ }^{[143]}$ as it is a well-established cause of cervical cancer. In addition to E6 and E7 transformations, HR HPV oncogenic types 16, 18, 31, 33, 35, 45, 52, 58, and 66 are associated closely with $>95 \%$ of cases of squamous cell carcinoma of the cervix. ${ }^{[144]}$ Moreover, only genotype HPV 16 accounts for $>55 \%$ of diagnosed tumors. ${ }^{[145]}$ Although infection with HR HPV is the major risk factor associated with cervical cancer, some studies have reported a possible tumor-initiating and promoting role in cervical cancer for other DNA tumor viruses. Taken together, this interaction may synergize with HPV in a normal cell to initiate and progress a tumorigenic cell. ${ }^{[146]}$

\section{ONCOGENIC DNA VIRUSES AND MODULATION OF THE NOTCH PATHWAY}

As previously discussed, the Notch signaling pathway influences cell fate decisions, proliferation versus differentiation, and cell survival. Similarly, viruses in infected cells promote cell survival, promote or block cell cycling and employ a variety of mechanisms to evade innate cellular anti-viral responses to ensure their own survival and multiplication. In light of these similarities, it is not surprising that several viruses highjack the Notch pathway to ensure the completion of their own life cycles. ${ }^{[147]}$

The first report of an interaction between a virus and the Notch pathway came from studies showing that binding of Epstein-Barr virus (EBV) nuclear antigen 2 (the transcriptional activator essential for EBV-driven B-cell immortalization) to responsive promoters requires the interaction with the nuclear effector of Notch signaling CSL. ${ }^{[148]}$ More recently, also, the Kaposi's sarcoma (KS)associated herpes virus replication and transcription activator protein (involved in controlling the switch from latency to lytic replication) has been found to activate lysisrelated gene by binding to CSL. ${ }^{[149]}$ Studies using $\gamma$-secretase 
inhibitors (GSI-I Z-Leu-Leu-Nle-CHO and LY-411, 575), small molecules which block Notch activation, resulted in apoptosis in KS cells and established KS cell tumors in mice, demonstrating the requirement for an active Notch signaling in KS. ${ }^{[150]}$ Notch pathway interactions have also been shown with adenoviral oncoprotein $13 \mathrm{~S}$ E1A, which binds to CSL, displaces associated corepressor complexes, and activates CSL-dependent gene expression. ${ }^{[151]}$

In agreement with reports of an association between SV40 infection and human mesothelioma, ${ }^{[152]}$ SV40 infection upregulates the expression of Notch1 in mesothelial cells. ${ }^{[153]}$ SV40-mediated Notch1 induction is achieved at the transcriptional level; it requires both SV40 Tag and tag and tag-induced activation of the mitogen-activated protein kinase-extracellular-signal-regulated kinase pathway. Notch activation is necessary for the growth of SV40-transformed mesothelial cells, as treatment of these cells with a Notch inhibitor leads to G2/M cell cycle arrest. ${ }^{[153]}$ Consistently, upregulation of Notch1 and ligands Jagged1 and 2 is maintained in SV40-transformed human mesothelial clones and SV40-positive mesotheliomas and derived cell lines. ${ }^{[153]}$

Other than in mesothelial cells, Notch1 expression and signaling has been linked to SV40-mediated transformation of primary astrocytes. ${ }^{[154]}$ In both mesothelial cells and astrocytes, SV40-mediated activation of Notch signaling determines the survival of cells grown in suspension. Of interest, the archetypal (1 copy of enhancer sequence in the regulatory region) and the non-archetypal ( 2 copies of enhancer sequences in the regulatory region) SV40 strains are both able to transform astrocytes whether only the nonarchetypal strain can transform mesothelial cells. Differences in expression levels of Notch 1 and its downstream effectors (c-Myc, Hey1, Hes1 and HeyL) appear to explain these differences in SV40-mediated transformation of primary astrocytes and mesothelial cells. ${ }^{[154]}$

SV40 tag, which forms a complex and inhibits PP2A activity, plays a critical role in the malignant transformation of human cells. Microarray analyses on human embryonic kidney cell lines overexpressing SV40 tag have identified induction of D111 and Jagged1 suggesting a role for SV40 tag in the activation of the Notch pathway. ${ }^{[155]}$ Of interest, in these cells, Notch signaling was found to be upregulated in association with Hedgehog and Wnt pathways but inhibition of Hedgehog and not of Notch interfered with cell survival suggesting that Notch signaling is not essential for survival in cells expressing SV40 tag. ${ }^{[155]}$ A link between SV40 tag and Notch has been observed also in human bronchial epithelial cells. Specifically, Wang et al. have shown that miR-27a is upregulated in SV40 tag-transformed human bronchial epithelial cells (HBERST) following the interaction between tag and PP2A. In these cells, miR27 a promotes cell cycle progression by downregulating Fbxw7, a regulator of ubiquitin-dependent proteolysis of a set of protein involved in cell cycle progression, including
Notch1. Suppression of miR-27a expression in HBERST cells leads to cell cycle arrest in the G0-G1 phase. ${ }^{[156]}$

Both SV40 Tag and tag have been shown to induce the immortalization of mammary gland epithelial cells. ${ }^{[157,158]}$ SV40 tag expression inhibits mammary gland differentiation during mid-pregnancy and about $10 \%$ of multiparous tag transgenic animals develop breast tumors with latencies ranging from 10 to 17 months, whereas expression of $\mathrm{N}$-terminal truncated Tag molecules harboring the intact p53 and pRB binding region does not have this effect. ${ }^{[158]}$ Expression of SV40 Tag in the epithelium of the mammary glands results in cancers which resemble the human disease and do not require hormone supplementation or pregnancy for insurgence. ${ }^{[157]}$ Breast cancer has been associated to SV40 infection ${ }^{[159]}$ and a specific gene signature in transgenic models of breast cancer intrinsic to the functions of the SV40 T/t-antigens has been identified which is associated with poor prognosis. ${ }^{[160]}$ It is not known whether SV40 is involved in the dysregulation of Notch signaling observed in breast cancer. ${ }^{[19,152]}$ Of interest, the Notch target gene cyclin D1 is overexpressed in the SV40 tag-positive mammary gland epithelial cells and in the breast tumor cells from SV40 tag-expressing mice. ${ }^{[157]}$

HPV is the most significant causative agent in the development of cervical cancer. Despite its presence in almost all cervical cancers, it is widely recognized that HPV by itself is unable to transform a normal cell to a cancerous one, and additional cellular mutations are required to supplement the HPV oncoproteins E6 and E7. The activation of the Notch signaling pathway induced by HPV infection has been proposed as one of the cellular changes that cooperate with the E6 and E7 proteins to cause cervical cancers. ${ }^{[161]}$ This proposition is based on several studies showing overexpression of Notch signaling in HPV-cervical cancer or cell lines. Specifically, active Notch1 expression has been shown in high-grade cervical lesions and cancers ${ }^{[162,163]}$ and progressively increasing upregulation of Notch3 expression with severity of disease as compared to normal cervix tissue has been reported in a set of 168 tissue biopsy samples comprising of tumor specimens, precancer, and non-neoplastic cervical tissues. ${ }^{[164]}$ Noteworthy, in the same specimens, Notch1 was found to be downregulated thus suggesting the existence of a complex interplay between Notch signaling and HPV in the context of the development of cervical carcinogenesis. ${ }^{[164]}$ Upregulation of both Jagged1 and Hes 1 and downregulation of Manic Fringe, a negative regulator of Jagged1-Notch1 signaling, have been shown in squamous cell carcinoma of cervix compared to high-grade lesions and in late-passage, but not early-passage, HPV type 16-positive human cervical low-grade lesion-derived cell line W12. ${ }^{[165]}$ Overexpression of all Notch receptors, Hes1, and MAML1, the transcriptional co-activator originally identified by its role in Notch signaling, has been found in $\mathrm{HeLa}$, SiHa, and CaSki, three other cell lines derived from 
HPV-positive human cervical cancer. ${ }^{[166]}$ Evidence in favor of an oncogenic role for Notch in cervical cancer comes from the observation that activated Notch1 synergizes with HPV16 E6 and E7 proteins in conferring apoptosis protection through the activation of the prosurvival PI3Kprotein kinase B/AKT (PI3K-PKB/AKT) pathway and in the transformation of the immortalized human keratinocytes $\mathrm{HaCaT}$ cell line. ${ }^{[167]}$ Furthermore, in HaCat cells active Notch1, through the PI3K-PKB/AKT-dependent pathway, inhibits p53-induced apoptosis and sustains transformation by HPV 16 E6 and E7. ${ }^{[168]}$ Consistently with the findings of high level of Jagged1 in cervical cancer, Jagged1 but not Dll1 expression correlates with the rapid induction of PI3K-mediated epithelial-mesenchymal transition both in $\mathrm{HaCaT}$ cells and in a human cervical tumor-derived cell line. ${ }^{[169]}$ Microarray studies by the same authors show that Notch-PI3K oncogenic functions can be independent of CSL activation and rely instead on Deltex 1, an alternative Notch effector ${ }^{[169]}$ The anti-apoptotic role played by Notch in cervical cancer progression has also been revealed by immunohistochemistry conducted in cervical cancer specimens in which high levels of Jagged 1, Hes 1, and Cdk9 were paralleled by nuclear translocation of both NF- $\kappa$ B p50

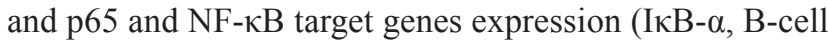
lymphoma 2 and cyclin D1). ${ }^{[170]}$ An active Notch pathway is necessary for the survival and the maintenance of the neoplastic phenotype of HPV-positive cervical cancer cell lines as demonstrated by experiments in which Notch signaling was inhibited by anti-sense Notch1 oligo, ${ }^{[46,171]}$ by upregulation of Manic Fringe, ${ }^{[165]}$ by small interfering RNA against Jagged ${ }^{[165]}$ or by inhibition of $\gamma$-secretase in combination with dominant negative MAML1, a regulator of crosstalk between the Notch and NF- $\kappa B$ pathways. ${ }^{[166]}$

Experimental evidence shows that as with SV40, HPV proteins have a direct effect on the activation of Notch signaling. Weijzen et al. have reported that transfection of mouse primary embryonic cells and human primary fibroblasts with HPV16 E6 and E7 upregulates Notch1 not only transcriptionally but also post-translationally by upregulating presenilin-1, a protein involved in Notch processing. ${ }^{[46]}$ Microarray analyses have revealed enhanced expression of Notch1 mRNA in HPV16 E6-expressing keratinocytes when NFX1-123 (a protein involved, together with E6, in binding and stabilization of mRNA coding for human telomerase reverse transcriptase, the catalytic subunit of telomerase) was overexpressed. A moderate increase in Notch1 mRNA was seen with overexpression of NFX1123 alone, but with 16E6 coexpression the increase in Notch1 was enhanced. ${ }^{[172]}$ A recent study by the same group has shown that the Notch canonical pathway genes Hes1 and Hes 5 were increased with overexpression of NFX1-123 in 16E6 - expressing keratinocytes, and their expression was directly linked to the activation or blockade of the Notch1 receptor. Of interest, keratin 1 and keratin 10 were also increased in this model, but in contrast to Notch target genes, their upregulation was only indirectly associated with Notch1 receptor stimulation, and it did not lead to growth arrest, increased p21 (Waf1/CIP1), or decreased proliferative factor Ki67. ${ }^{[173]}$

Notch signaling pathway is a key determinant of keratinocyte growth arrest and differentiation. ${ }^{[174]}$ and it has been recently shown that it promotes expression of differentiation markers acting together with the TAp63 $\beta$ isoform of the p63 transcription factor. ${ }^{[175]}$ This evidence supports a role for Notch as putative tumor suppressor in $\mathrm{HPV}$-associated tumorigenesis rather than an oncogene, as discussed so far. It is well established that Notch activity regulates tumor biology in a context-dependent manner and may act as an oncogene or a tumor-suppressor gene within the same tumor type. In human, esophageal keratinocytes overexpression of Notch1 induces senescence (induction of G0/G1 cell-cycle arrest, Rb dephosphorylation, flat and enlarged cell morphology, and senescence-associated beta-galactosidase activity) requiring both canonical CSLdependent transcriptional activity and the p16INK4A-Rb pathway. Loss of p16INK4A or the presence of HPVE6/E7 oncogene products (which inactivate both the p53 and pRB) in these cells have been shown not only to prevent intracellular Notch1 (N1IC) from inducing senescence, but also to facilitate N1IC-mediated anchorage-independent colony formation and xenograft tumor growth with increased cell proliferation and reduced squamous-cell differentiation. ${ }^{[176]}$ These observations provide a possible molecular mechanism to explain and support the hypothesis of the oncogenic role on Notch in HPV-positive cervical cancer.

In agreement with a protective role of Notch against HPV-induced transformation, Talora et al. have reported that the expression of the endogenous Notch1 gene is markedly reduced in a panel of cervical carcinoma cells, whereas expression of Notch 2 remains elevated, and Notch1 expression is reduced or absent in invasive cervical cancers. ${ }^{[177]}$ The authors show that increased Notch1 signaling, but not Notch2, causes a dramatic downmodulation of HPV-driven transcription of the E6/E7 viral genes, through suppression of AP-1 activity by upregulation of the Fra-1 family member and decreased c-Fos expression. According to the authors, the downmodulation of Notch1 expression would play an important role in late stages of HPV-induced carcinogenesis. ${ }^{[177]}$ In agreement with these observations, E6 protein from cutaneous HPVs of the $\beta$-genus, such as bovine papillomavirus Type 1 and $\beta$-HPV5 and 8 , induces a repression of Notch transcriptional activation, which is dependent on an interaction with MAML1 ${ }^{[178-180]}$ and it has been shown to inhibit keratinocyte differentiation. ${ }^{[181]}$

Technical approaches (type of anti-body used) for Notch detection have been invoked to explain the differences in expression levels of Notch in HPV-positive cervical tumors linked to the different roles of Notch as an oncogene or tumor suppressor gene. ${ }^{[182]}$ As previously discussed, the opposite 
roles on Notch in the context of HPV-cervical cancer have also been attributed to the cellular context. Extremely high levels of Notch1 seem to adversely affect HPV E6 and E7 expression and cellular proliferation whereas moderate levels of Notch1 and PI3K exhibit oncogenic properties that transform primary cells containing HPV16 E6 and E7 proteins. ${ }^{[161]}$ More recently, in SiHa cervical cancer cells, it was shown that moderate Notch activation contributed to increased viability and anchorage independent growth, whereas high-level Notch activation decreased anchorage independent growth. The shift in phenotypical outcome was correlated to altered AP-1 activity and complex composition. ${ }^{[183]}$

Interactions between the Notch pathway and HPV may play a role also in the progression of head and neck squamous cell carcinoma. Exome sequencing of head and neck squamous cell carcinoma have revealed inactivating mutations in Notch $1^{[184]}$ and recent work by Seiwert et al. has shown an enrichment in the frequency of Notch1 mutations in HPV-positive compared to HPV-negative head and neck squamous cell carcinomas. ${ }^{[185]}$

\section{CONCLUSION}

Many reports indicate that dysregulated Notch pathway and oncogenic viruses may act together in the initiation and progression of different human tumors. More investigations are necessary to acquire new knowledge on the molecular mechanisms involved in the oncogenic process, which are regulated by oncogenic viruses-mediated Notch dysregulation [Figure 1]. These studies could lead to the identification of biomarkers or the development of targeted therapeutic approaches specific for Notchassociated malignancies characterized by the presence of the oncogenic viruses. Furthermore, considering the role of Notch in the regulation of the host immune response against viral infections, a deeper understanding of the interactions between oncogenic viruses and the Notch pathway could lead to the targeting of Notch to prevent or reduce oncogenic virus infections and, possibly, onset of cancers associated with exposure to these viruses.

\section{Acknowledgments}

The works of the authors reported in this review were supported by funds from Associazione Italiana per la Ricerca sul Cancro, Milan, to MT, and Fondazione Berlucchi, Brescia, to Maniac Fringe. We thank Dr. Elisa Mazzoni, fellow of the Fondazione Veronesi, Milan, for the excellent assistance in the editing of the manuscript.

\section{Financial support and sponsorship} Nil.

\section{Conflicts of interest}

There are no conflicts of interest.

\section{REFERENCES}

1. Borggrefe T, Liefke R. Fine-tuning of the intracellular canonical Notch signaling pathway. Cell Cycle 2012;11:264-76.

2. Artavanis-Tsakonas S, Muskavitch MA. Notch: the past, the present, and the future. Curr Top Dev Biol 2010;92:1-29.

3. Gordon WR, Zimmerman B, He L, Miles LJ, Huang JH, Tiyanont K, McArthur DG, Aster JC, Perrimon N, Loparo JJ, Blacklow SC. Mechanical allostery: evidence for a force requirement in the proteolytic activation of notch. Dev Cell 2015;33:729-36.

4. Brou C, Logeat F, Gupta N, Bessia C, LeBail O, Doedens JR, Cumano A, Roux P, Black RA, Israel A. A novel proteolytic cleavage involved in Notch signaling: the role of the disintegrinmetalloprotease TACE. Mol Cell 2000;5:207-16.

5. Kopan R, Ilagan MX. Gamma-secretase: proteasome of the membrane? Nat Rev Mol Cell Biol 2004;5:499-504.

6. Tamura K, Taniguchi Y, Minoguchi S, Sakai T, Tun T, Furukawa T, Honjo T. Physical interaction between a novel domain of the receptor Notch and the transcription factor RBP-J kappa/Su(H). Curr Biol 1995;5:1416-23.

7. Wu L, Aster JC, Blacklow SC, Lake R, Artavanis-Tsakonas S, Griffin JD. MAML1, a human homologue of Drosophila mastermind, is a transcriptional co-activator for NOTCH receptors. Nat Genet 2000;26:484-9.

8. Espinoza I, Miele L. Notch inhibitors for cancer treatment Pharmacol Ther 2013;139:95-110.

9. Ronchini C, Capobianco AJ. Induction of cyclin D1 transcription and CDK2 activity by Notch(IC): implication for cell cycle disruption in transformation by Notch(ic). Mol Cell Biol 2001;21:5925-34.

10. Li L, Zhao F, Lu J, Li T, Yang H, Wu C, Liu Y. Notch-1 signaling promotes the malignant features of human breast cancer through NFkappaB activation. PLoS One 2014;9:e95912.

11. Osipo C, Golde TE, Osborne BA, Miele LA. Off the beaten pathway: the complex cross talk between Notch and NF-kappaB. Lab Invest 2008;88:11-7.

12. Yamamizu K, Matsunaga T, Uosaki H, Fukushima H, Katayama S, Hiraoka-Kanie M, Mitani K, Yamashita JK. Convergence of Notch and beta-catenin signaling induces arterial fate in vascular progenitors. J Cell Biol 2010;189:325-38.

13. Dongre A, Surampudi L, Lawlor RG, Fauq AH, Miele L, Golde TE, Minter LM, Osborne BA. Non-canonical Notch signaling drives activation and differentiation of peripheral CD4(+) T Cells. Front Immunol 2014;5:54.

14. Hao L, Rizzo P, Osipo C, Pannuti A, Wyatt D, Cheung LW, Sonenshein G, Osborne BA, Miele L. Notch-1 activates estrogen receptor-alpha-dependent transcription via IKKalpha in breast cancer cells. Oncogene 2010;29:201-13.

15. Perumalsamy LR, Nagala M, Sarin A. Notch-activated signaling cascade interacts with mitochondrial remodeling proteins to regulate cell survival. Proc Natl Acad Sci U S A 2010;107:6882-7.

16. Yun J, Espinoza I, Pannuti A, Romero D, Martinez L, Caskey M, Stanculescu A, Bocchetta M, Rizzo P, Band V, Band H, Kim HM, Park SK, Kang KW, Avantaggiati ML, Gomez CR, Golde T, Osborne B, Miele L. p53 modulates Notch signaling in MCF-7 breast cancer cells by associating with the Notch transcriptional complex via MAML1. J Cell Physiol 2015;230:3115-27.

17. Caliceti C, Aquila G, Pannella M, Morelli MB, Fortini C, Pinton P, Bonora M, Hrelia S, Pannuti A, Miele L, Rizzo P, Ferrari R. 17beta-estradiol enhances signalling mediated by VEGF-A-deltalike ligand 4-notch1 axis in human endothelial cells. PLoS One 2013;8:e71440.

18. Rizzo P, Miao H, D’Souza G, Osipo C, Song LL, Yun J, Zhao H, Mascarenhas J, Wyatt D, Antico G, Hao L, Yao K, Rajan P, Hicks C, Siziopikou K, Selvaggi S, Bashir A, Bhandari D, Marchese A, Lendahl U, Qin JZ, Tonetti DA, Albain K, Nickoloff BJ, Miele L. 
Cross-talk between notch and the estrogen receptor in breast cancer suggests novel therapeutic approaches. Cancer Res 2008;68:5226-35.

19. Osipo C, Patel P, Rizzo P, Clementz AG, Hao L, Golde TE, Miele L. ErbB-2 inhibition activates Notch-1 and sensitizes breast cancer cells to a gamma-secretase inhibitor. Oncogene 2008;27:5019-32.

20. Benedito R, Rocha SF, Woeste M, Zamykal M, Radtke F, Casanovas O, Duarte A, Pytowski B, Adams RH. Notch-dependent VEGFR3 upregulation allows angiogenesis without VEGF-VEGFR2 signalling. Nature 2012;484:110-4.

21. Caliceti C, Nigro P, Rizzo P, Ferrari R. ROS, Notch, and Wnt signaling pathways: crosstalk between three major regulators of cardiovascular biology. Biomed Res Int 2014;2014:318714.

22. Romero-Carvajal A, Navajas Acedo J, Jiang L, KozlovskajaGumbriene A, Alexander R, Li H, Piotrowski T. Regeneration of sensory hair cells requires localized interactions between the Notch and Wnt pathways. Dev Cell 2015;34:267-82.

23. Xie G, Karaca G, Swiderska-Syn M, Michelotti GA, Kruger L, Chen Y, Premont RT, Choi SS, Diehl AM. Cross-talk between Notch and Hedgehog regulates hepatic stellate cell fate in mice. Hepatology 2013;58:1801-13.

24. Guruharsha KG, Kankel MW, Artavanis-Tsakonas S. The Notch signalling system: recent insights into the complexity of a conserved pathway. Nat Rev Genet 2012;13:654-66.

25. de la Pompa JL, Epstein JA. Coordinating tissue interactions: notch signaling in cardiac development and disease. Dev Cell 2012;22:244-54.

26. Gridley T. Notch signaling in the vasculature. Notch Signal 2010;92:277-309.

27. Gude N, Joyo E, Toko H, Quijada P, Villanueva M, Hariharan N, Sacchi V, Truffa S, Joyo A, Voelkers M, Alvarez R, Sussman MA. Notch activation enhances lineage commitment and protective signaling in cardiac progenitor cells. Basic Res Cardiol 2015;110:29.

28. Apelqvist A, Li H, Sommer L, Beatus P, Anderson DJ, Honjo T, Hrabe de Angelis M, Lendahl U, Edlund H. Notch signalling controls pancreatic cell differentiation. Nature 1999;400:877-81.

29. Lanford PJ, Lan Y, Jiang R, Lindsell C, Weinmaster G, Gridley T, Kelley MW. Notch signalling pathway mediates hair cell development in mammalian cochlea. Nat Genet 1999;21:289-92.

30. van Es JH, van Gijn ME, Riccio O, van den Born M, Vooijs M, Begthel H, Cozijnsen M, Robine S, Winton DJ, Radtke F, Clevers H. Notch/gamma-secretase inhibition turns proliferative cells in intestinal crypts and adenomas into goblet cells. Nature 2005;435:959-63.

31. Gridley T. Notch signaling and inherited disease syndromes. Hum Mol Genet 2003;12:R9-13.

32. High FA, Epstein JA. The multifaceted role of Notch in cardiac development and disease. Nat Rev Genet 2008;9:49-61.

33. Radtke F, Fasnacht N, Macdonald HR. Notch signaling in the immune system. Immunity 2010;32:14-27.

34. Ito T, Allen RM, Carson WF, Schaller M, Cavassani KA, Hogaboam CM, Lukacs NW, Matsukawa A, Kunkel SL. The critical role of Notch ligand Delta-like 1 in the pathogenesis of influenza A virus (H1N1) infection. PLoS Pathog 2011;7:e1002341.

35. Li Y, Wu S, Pu J, Huang X, Zhang P. Dengue virus up-regulates expression of notch ligands D111 and Dll4 through interferon-beta signalling pathway. Immunology 2015;144:127-38.

36. Ellisen LW, Bird J, West DC, Soreng AL, Reynolds TC, Smith SD, Sklar J. TAN-1, the human homolog of the Drosophila notch gene, is broken by chromosomal translocations in T lymphoblastic neoplasms. Cell 1991;66:649-61.

37. Pear WS, Aster JC, Scott ML, Hasserjian RP, Soffer B, Sklar J, Baltimore D. Exclusive development of T cell neoplasms in mice transplanted with bone marrow expressing activated Notch alleles. J Exp Med 1996;183:2283-91.

38. Weng AP, Ferrando AA, Lee W, Morris JPt, Silverman LB,
Sanchez-Irizarry C, Blacklow SC, Look AT, Aster JC. Activating mutations of NOTCH1 in human $\mathrm{T}$ cell acute lymphoblastic leukemia. Science 2004;306:269-71.

39. Weng AP, Millholland JM, Yashiro-Ohtani Y, Arcangeli ML, Lau A, Wai C, Del Bianco C, Rodriguez CG, Sai H, Tobias J, Li Y, Wolfe MS, Shachaf C, Felsher D, Blacklow SC, Pear WS, Aster JC. c-Myc is an important direct target of Notch1 in T-cell acute lymphoblastic leukemia/lymphoma. Genes Dev 2006;20:2096-109.

40. Palomero T, Sulis ML, Cortina M, Real PJ, Barnes K, Ciofani M, Caparros E, Buteau J, Brown K, Perkins SL, Bhagat G, Agarwal AM, Basso G, Castillo M, Nagase S, Cordon-Cardo C, Parsons R, Zuniga-Pflucker JC, Dominguez M, Ferrando AA. Mutational loss of PTEN induces resistance to NOTCH1 inhibition in T-cell leukemia. Nat Med 2007;13:1203-10.

41. Witkowski MT, Cimmino L, Hu Y, Trimarchi T, Tagoh H, McKenzie MD, Best SA, Tuohey L, Willson TA, Nutt SL, Busslinger M, Aifantis I, Smyth GK, Dickins RA. Activated Notch counteracts Ikaros tumor suppression in mouse and human T-cell acute lymphoblastic leukemia. Leukemia 2015;29:1301-11.

42. Gallahan D, Jhappan C, Robinson G, Hennighausen L, Sharp R, Kordon E, Callahan R, Merlino G, Smith GH. Expression of a truncated Int3 gene in developing secretory mammary epithelium specifically retards lobular differentiation resulting in tumorigenesis. Cancer Res 1996;56:1775-85.

43. Hu C, Dievart A, Lupien M, Calvo E, Tremblay G, Jolicoeur P. Overexpression of activated murine Notch 1 and Notch 3 in transgenic mice blocks mammary gland development and induces mammary tumors. Am J Pathol 2006;168:973-90.

44. Li ZL, Chen C, Yang Y, Wang C, Yang T, Yang X, Liu SC. Gamma secretase inhibitor enhances sensitivity to doxorubicin in MDAMB-231 cells. Int J Clin Exp Pathol 2015;8:4378-87.

45. Yao K, Rizzo P, Rajan P, Albain K, Rychlik K, Shah S, Miele L. Notch-1 and notch-4 receptors as prognostic markers in breast cancer. Int J Surg Pathol 2011;19:607-13.

46. Weijzen S, Rizzo P, Braid M, Vaishnav R, Jonkheer SM, Zlobin A, Osborne BA, Gottipati S, Aster JC, Hahn WC, Rudolf M, Siziopikou K, Kast WM, Miele L. Activation of Notch-1 signaling maintains the neoplastic phenotype in human Ras-transformed cells. Nat Med 2002;8:979-86.

47. Wang K, Zhang Q, Li D, Ching K, Zhang C, Zheng X, Ozeck M, Shi S, Li X, Wang H, Rejto P, Christensen J, Olson P. PEST domain mutations in Notch receptors comprise an oncogenic driver segment in triple-negative breast cancer sensitive to a gammasecretase inhibitor. Clin Cancer Res 2015;21:1487-96.

48. Reedijk M, Odorcic S, Chang L, Zhang H, Miller N, McCready DR, Lockwood G, Egan SE. High-level coexpression of JAG1 and NOTCH1 is observed in human breast cancer and is associated with poor overall survival. Cancer Res 2005;65:8530-7.

49. Parr C, Watkins G, Jiang WG. The possible correlation of Notch-1 and Notch-2 with clinical outcome and tumour clinicopathological parameters in human breast cancer. Int J Mol Med 2004;14:779-86.

50. O’Neill CF, Urs S, Cinelli C, Lincoln A, Nadeau RJ, Leon R, Toher J, Mouta-Bellum C, Friesel RE, Liaw L. Notch2 signaling induces apoptosis and inhibits human MDA-MB-231xenograft growth. Am J Pathol 2007;171:1023-36.

51. Harrison H, Farnie G, Howell SJ, Rock RE, Stylianou S, Brennan KR, Bundred NJ, Clarke RB. Regulation of breast cancer stem cell activity by signaling through the Notch4 receptor. Cancer Res 2010;70:709-18.

52. Selever J, Gu G, Lewis MT, Beyer A, Herynk MH, Covington KR, Tsimelzon A, Dontu G, Provost P, Di Pietro A, Boumendjel A, Albain K, Miele L, Weiss H, Barone I, Ando S, Fuqua SA. Dicer-mediated upregulation of BCRP confers tamoxifen resistance in human breast cancer cells. Clin Cancer Res 2011;17:6510-21.

53. Yun J, Pannuti A, Espinoza I, Zhu H, Hicks C, Zhu X, Caskey M, Rizzo P, D’Souza G, Backus K, Denning MF, Coon J, Sun M, 
Bresnick EH, Osipo C, Wu J, Strack PR, Tonetti DA, Miele L. Crosstalk between PKCalpha and Notch-4 in endocrine-resistant breast cancer cells. Oncogenesis 2013;2:e60.

54. Pandya K, Meeke K, Clementz AG, Rogowski A, Roberts J, Miele L, Albain KS, Osipo C. Targeting both Notch and ErbB-2 signalling pathways is required for prevention of ErbB-2-positive breast tumour recurrence. Br J Cancer 2011;105:796-806.

55. Folkman J. Tumor angiogenesis: therapeutic implications. $N$ Engl $J$ Med 1971;285:1182-6

56. Jakobsson L, Bentley K, Gerhardt H. VEGFRs and Notch: a dynamic collaboration in vascular patterning. Biochem Soc Trans 2009;37:1233-6.

57. Gu JW, Rizzo P, Pannuti A, Golde T, Osborne B, Miele L. Notch signals in the endothelium and cancer "stem-like" cells: opportunities for cancer therapy. Vasc Cell 2012;4:7.

58. Boareto M, Jolly MK, Ben-Jacob E, Onuchic JN. Jagged mediates differences in normal and tumor angiogenesis by affecting tip-stalk fate decision. Proc Natl Acad Sci U S A 2015;112:E3836-44.

59. Pedrosa AR, Trindade A, Carvalho C, Graca J, Carvalho S, Peleteiro MC, Adams RH, Duarte A. Endothelial Jagged1 promotes solid tumor growth through both pro-angiogenic and angiocrine functions. Oncotarget 2015;6:24404-23.

60. Kangsamaksin T, Murtomaki A, Kofler NM, Cuervo H, Chaudhri RA, Tattersall IW, Rosenstiel PE, Shawber CJ, Kitajewski J. $\mathrm{NOTCH}$ decoys that selectively block DLL/ NOTCH or JAG/ $\mathrm{NOTCH}$ disrupt angiogenesis by unique mechanisms to inhibit tumor growth. Cancer Discov 2015;5:182-97.

61. Takebe N, Miele L, Harris PJ, Jeong W, Bando H, Kahn M, Yang SX, Ivy SP. Targeting Notch, Hedgehog, and Wnt pathways in cancer stem cells: clinical update. Nat Rev Clin Oncol 2015;12:445-64.

62. Wei P, Walls M, Qiu M, Ding R, Denlinger RH, Wong A, Tsaparikos K, Jani JP, Hosea N, Sands M, Randolph S, Smeal T. Evaluation of selective gamma-secretase inhibitor PF-03084014 for its antitumor efficacy and gastrointestinal safety to guide optimal clinical trial design. Mol Cancer Ther 2010;9:1618-28.

63. Smith DC, Eisenberg PD, Manikhas G, Chugh R, Gubens MA, Stagg RJ, Kapoun AM, Xu L, Dupont J, Sikic B. A phase I dose escalation and expansion study of the anticancer stem cell agent demcizumab (anti-DLL4) in patients with previously treated solid tumors. Clin Cancer Res 2014;20:6295-303.

64. Westhoff B, Colaluca IN, D’Ario G, Donzelli M, Tosoni D, Volorio S, Pelosi G, Spaggiari L, Mazzarol G, Viale G, Pece S, Di Fiore PP. Alterations of the Notch pathway in lung cancer. Proc Natl Acad Sci U S A 2009;106:22293-8.

65. Sun W, Gaykalova DA, Ochs MF, Mambo E, Arnaoutakis D, Liu Y, Loyo M, Agrawal N, Howard J, Li R, Ahn S, Fertig E, Sidransky D, Houghton J, Buddavarapu K, Sanford T, Choudhary A, Darden W, Adai A, Latham G, Bishop J, Sharma R, Westra WH, Hennessey P, Chung $\mathrm{CH}$, Califano JA. Activation of the NOTCH pathway in head and neck cancer. Cancer Res 2014;74:1091-104

66. Pece S, Serresi M, Santolini E, Capra M, Hulleman E, Galimberti V, Zurrida S, Maisonneuve P, Viale G, Di Fiore PP. Loss of negative regulation by Numb over Notch is relevant to human breast carcinogenesis. J Cell Biol 2004;167:215-21.

67. Robinson DR, Kalyana-Sundaram S, Wu YM, Shankar S, Cao X, Ateeq B, Asangani IA, Iyer M, Maher CA, Grasso CS, Lonigro RJ, Quist M, Siddiqui J, Mehra R, Jing X, Giordano TJ, Sabel MS, Kleer CG, Palanisamy N, Natrajan R, Lambros MB, ReisFilho JS, Kumar-Sinha C, Chinnaiyan AM. Functionally recurrent rearrangements of the MAST kinase and Notch gene families in breast cancer. Nat Med 2011;17:1646-51.

68. Sweet BH, Hilleman MR. The vacuolating virus, S.V. 40. Proc Soc Exp Biol Med 1960;105:420-7.

69. Barbanti-Brodano G, Sabbioni S, Martini F, Negrini M, Corallini A, Tognon M. Simian virus 40 infection in humans and association with human diseases: results and hypotheses. Virology 2004;318:1-9.

70. Martini F, Corallini A, Balatti V, Sabbioni S, Pancaldi C, Tognon M. Simian virus 40 in humans. Infect Agent Cancer 2007;2:13.

71. Cutrone R, Lednicky J, Dunn G, Rizzo P, Bocchetta M, Chumakov $\mathrm{K}$, Minor $\mathrm{P}$, Carbone M. Some oral poliovirus vaccines were contaminated with infectious SV40 after 1961. Cancer Res 2005;65:10273-9.

72. Butel JS, Lednicky JA. Cell and molecular biology of simian virus 40: implications for human infections and disease. $J$ Natl Cancer Inst 1999;91:119-34.

73. Jasani B, Cristaudo A, Emri SA, Gazdar AF, Gibbs A, Krynska B, Miller C, Mutti L, Radu C, Tognon M, Procopio A. Association of SV40 with human tumours. Semin Cancer Biol 2001;11:49-61.

74. Butel JS. Patterns of polyomavirus SV40 infections and associated cancers in humans: a model. Curr Opin Virol 2012;2:508-14.

75. Melnick JL. Papova virus group. Science 1962;135:1128-30.

76. Alwine JC. Evidence for simian virus 40 late transcriptional control: mixed infections of wild-type simian virus 40 and a late leader deletion mutant exhibit trans effects on late viral RNA synthesis. J Virol 1982;42:798-803.

77. Hay N, Skolnik-David H, Aloni Y. Attenuation in the control of SV40 gene expression. Cell 1982;29:183-93.

78. Ng SC, Mertz JE, Sanden-Will S, Bina M. Simian virus 40 maturation in cells harboring mutants deleted in the agnogene. $J$ Biol Chem 1985;260:1127-32.

79. Sullivan CS, Grundhoff AT, Tevethia S, Pipas JM, Ganem D. SV40encoded microRNAs regulate viral gene expression and reduce susceptibility to cytotoxic T cells. Nature 2005;435:682-6.

80. Alwine JC, Khoury G. Simian virus 40-associated small RNA: mapping on the simian virus 40 genome and characterization of its synthesis. J Virol 1980;36:701-8.

81. Takemoto KK, Mullarkey MF. Human papovavirus, BK strain: biological studies including antigenic relationship to simian virus 40 . J Virol 1973;12:625-31.

82. Walker DL, Padgett BL, Zu Rhein G, Albert A, Marsh R. Current study of an opportunistic papovavirus. In: Zeman W, Lennette EH, editors. Slow Virus Disease. Baltimore: Williams and Wilkins; 1973. p. 49-58.

83. Shah KV, Ozer HL, Ghazey HN, Kelly TJ Jr. Common structural antigen of papovaviruses of the simian virus 40-polyoma subgroup. J Virol 1977;21:179-86.

84. Yang RC, Wu R. BK virus DNA: complete nucleotide sequence of a human tumor virus. Science 1979;206:456-62.

85. Frisque RJ, Bream GL, Cannella MT. Human polyomavirus JC virus genome. J Virol 1984;51:458-69.

86. Garcea RL, Imperiale MJ. Simian virus 40 infection of humans. J Virol 2003;77:5039-45.

87. Barbanti-Brodano G, Martini F, De Mattei M, Lazzarin L, Corallini A, Tognon M. BK and JC human polyomaviruses and simian virus 40: natural history of infection in humans, experimental oncogenicity, and association with human tumors. Adv Virus Res 1998;50:69-99

88. Imperiale MJ. Oncogenic transformation by the human polyomaviruses. Oncogene 2001;20:7917-23.

89. Imperiale MJ. The human polyomaviruses: an overview. In: Khalili K, Stoner GL, editors. Human Polyomaviruses: molecular and Clinical Perspectives. New York: Wiley-Liss, Inc.; 2001. p. 53-71.

90. Hurault de Ligny B, Godin M, Lobbedez T, El Haggan W, Pujo M, Etienne I, Ryckelynck JP. Virological, epidemiological and pathogenic aspects of human polyomaviruses. Presse Med 2003;32:656-8.

91. Pipas JM, Levine AJ. Role of T antigen interactions with $\mathrm{p} 53$ in tumorigenesis. Semin Cancer Biol 2001;11:23-30.

92. Saenz-Robles MT, Sullivan CS, Pipas JM. Transforming functions of simian virus 40. Oncogene 2001;20:7899-907.

93. Dyson N, Bernards R, Friend SH, Gooding LR, Hassell JA, Major EO, Pipas JM, Vandyke T, Harlow E. Large T antigens of many 
polyomaviruses are able to form complexes with the retinoblastoma protein. J Virol 1990;64:1353-6.

94. Sheppard HM, Corneillie SI, Espiritu C, Gatti A, Liu X. New insights into the mechanism of inhibition of $\mathrm{p} 53$ by simian virus 40 large T antigen. Mol Cell Biol 1999;19:2746-53.

95. Theile M, Strauss M, Luebbe L, Scherneck S, Krause H, Geissler E. SV40induced somatic mutations: possible relevance to viral transformation. Cold Spring Harb Symp Quant Biol 1980;44(Pt 1):377-82.

96. Ray FA, Peabody DS, Cooper JL, Cram LS, Kraemer PM. SV40 $\mathrm{T}$ antigen alone drives karyotype instability that precedes neoplastic transformation of human diploid fibroblasts. J Cell Biochem 1990;42:13-31.

97. Stewart N, Bacchetti S. Expression of SV40 large T antigen, but not small $\mathrm{t}$ antigen, is required for the induction of chromosomal aberrations in transformed human cells. Virology 1991;180:49-57.

98. Tognon M, Casalone R, Martini F, De Mattei M, Granata P, Minelli E, Arcuri C, Collini P, Bocchini V. Large T antigen coding sequences of two DNA tumor viruses, BK and SV40, and nonrandom chromosome changes in two glioblastoma cell lines. Cancer Genet Cytogenet 1996;90:17-23.

99. Gaillard S, Fahrbach KM, Parkati R, Rundell K. Overexpression of simian virus 40 small- $\mathrm{T}$ antigen blocks centrosome function and mitotic progression in human fibroblasts. J Virol 2001;75:9799-807.

100. Zhao JJ, Gjoerup OV, Subramanian RR, Cheng Y, Chen W, Roberts TM, Hahn WC. Human mammary epithelial cell transformation through the activation of phosphatidylinositol 3-kinase. Cancer Cell 2003;3:483-95.

101. Bleeker FE, Lamba S, Zanon C, Molenaar RJ, Hulsebos TJ, Troost D, van Tilborg AA, Vandertop WP, Leenstra S, van Noorden CJ, Bardelli A. Mutational profiling of kinases in glioblastoma. $B M C$ Cancer 2014;14:718

102. Bleeker FE, Molenaar RJ, Leenstra S. Recent advances in the molecular understanding of glioblastoma. J Neurooncol 2012;108:11-27.

103. Beck GZ Jr, Zerler BR, Moran E. Introduction to DNA tumor viruses: adenovirus, simian virus 40 , and polyomavirus. In: McCance DJ, editor. Human Tumor Viruses. Washington, DC: ASM Press; 1998. p. 51-86.

104. Loeken MR. Simian virus 40 small $\mathrm{t}$ antigen trans activates the adenovirus E2A promoter by using mechanisms distinct from those used by adenovirus E1A. J Virol 1992;66:2551-5.

105. Shein HM, Enders JF. Transformation induced by simian virus 40 in human renal cell cultures. I. Morphology and growth characteristics. Proc Natl Acad Sci U S A 1962;48:1164-72.

106. Koprowski H, Ponten J, Jensen F, Ravdin RG, Moorhead P, Saksela E. Transformation of cultures of human tissue infected with simian virus SV40. Acta Unio Int Contra Cancrum 1963;19:362-7.

107. Jensen F, Koprowski H, Pagano JS, Ponten J, Ravdin RG. Autologous and homologous implantation of human cells transformed in vitro by simian virus 40. J Natl Cancer Inst 1964;32:917-37.

108. Chen W, Hahn WC. SV40 early region oncoproteins and human cell transformation. Histol Histopathol 2003;18:541-50.

109. Hahn WC, Counter CM, Lundberg AS, Beijersbergen RL, Brooks MW, Weinberg RA. Creation of human tumour cells with defined genetic elements. Nature 1999;400:464-8.

110. Diamandopoulos GT. Leukemia, lymphoma, and osteosarcoma induced in the Syrian golden hamster by simian virus 40 . Science 1972;176:173-5.

111. Cicala C, Pompetti F, Carbone M. SV40 induces mesotheliomas in hamsters. Am J Pathol 1993;142:1524-33.

112. Coe JE, Green I. B-cell origin of hamster lymphoid tumors induced by simian virus 40. J Natl Cancer Inst 1975;54:269-70.

113. Van Dyke TA, Finlay C, Miller D, Marks J, Lozano G, Levine AJ. Relationship between simian virus 40 large tumor antigen expression and tumor formation in transgenic mice. $J$ Virol 1987;61:2029-32.

114. Brinster RL, Chen HY, Messing A, van Dyke T, Levine AJ,
Palmiter RD. Transgenic mice harboring SV40 T-antigen genes develop characteristic brain tumors. Cell 1984;37:367-79.

115. Palmiter RD, Chen HY, Messing A, Brinster RL. SV40 enhancer and large-T antigen are instrumental in development of choroid plexus tumours in transgenic mice. Nature 1985;316:457-60.

116. Feigenbaum L, Hinrichs SH, Jay G. JC virus and simian virus 40 enhancers and transforming proteins: role in determining tissue specificity and pathogenicity in transgenic mice. $J$ Virol 1992;66:1176-82.

117. Butel J. Polyomavirus SV40: model infectious agent of cancer. In: Robertson ES, editor. Cancer Associated Viruses. Current Cancer Research ID1. Perelman School of Medicine, University of Pennsylvania; Springer US; 2012. p. 377-417.

118. Martini F, De Mattei M, Iaccheri L, Lazzarin L, Barbanti-Brodano G, Tognon M, Gerosa M. Human brain tumors and simian virus 40 . J Natl Cancer Inst 1995;87:1331.

119. Martini F, Iaccheri L, Lazzarin L, Carinci P, Corallini A, Gerosa M, Iuzzolino P, Barbanti-Brodano G, Tognon M. SV40 early region and large $\mathrm{T}$ antigen in human brain tumors, peripheral blood cells, and sperm fluids from healthy individuals. Cancer Res 1996;56:4820-5.

120. David H, Mendoza S, Konishi T, Miller CW. Simian virus 40 is present in human lymphomas and normal blood. Cancer Lett 2001;162:57-64.

121. Pancaldi C, Balatti V, Guaschino R, Vaniglia F, Corallini A, Martini F, Mutti L, Tognon M. Simian virus 40 sequences in blood specimens from healthy individuals of Casale Monferrato, an industrial town with a history of asbestos pollution. J Infect 2009;58:53-60.

122. Mazzoni E, Corallini A, Cristaudo A, Taronna A, Tassi G, Manfrini M, Comar M, Bovenzi M, Guaschino R, Vaniglia F, Magnani C, Casali F, Rezza G, Barbanti Brodano G, Martini F, Tognon M. High prevalence of serum antibodies reacting wuth simian virus 40 capsid protein minotopes in patients affected by malignant pleural mesothelioma. Proc Natl Acad Sci U S A 2012;109:18066-71.

123. Mazzoni E, Gerosa M, Lupidi F, Corallini A, Taronna AP, D’Agostino A, Bovenzi M, Ruggeri G, Casali F, Rotondo JC, Rezza G, Barbanti-Brodano G, Tognon M, Martini F. Significant prevalence of antibodies reacting with simian virus 40 mimotopes in sera from patients affected by glioblastoma multiforme. Neurooncology 2014;16:513-9.

124. Mazzoni E, Benassi MS, Corallini A, Barbanti-Brodano G, Taronna A, Picci P, Guerra G, D’Agostino A, Trevisiol L, Nocini PF, Casali MV, Martini F, Tognon M. Significant association between human osteosarcoma and simian virus 40. Cancer 2015;121:708-15.

125. Bononi I, Perri P, Begnardi A, Martini A, Mazzoni E, Bosi S, Pietrobon S, Sebastiani A, Tognon M, Martini F. Antibodies reacting with simian virus 40 capsid protein mimotopes in serum samples from patients affected by uveal melanoma. J Hematol Oncol 2014;7:38.

126. Tognon M, Luppi M, Corallini A, Taronna A, Barozzi P, Rotondo JC, Comar M, Casali MV, Bovenzi M, D’Agostino A, Vinante F, Rigo A, Ferrarini I, Barbanti-Brodano G, Martini F, Mazzoni E. Immunologic evidence of a strong association between non-Hodgkin lymphoma and simian virus 40. Cancer 2015;121:2618-26.

127. Corallini A, Mazzoni E, Taronna A, Manfrini M, Carandina G, Guerra G, Guaschino R, Vaniglia F, Magnani C, Casali F, Dolcetti R, Palmonari C, Rezza G, Martini F, Barbanti-Brodano G, Tognon MG. Specific antibodies reacting with simian virus 40 capsid protein mimotopes in serum samples from healthy blood donors. Hum Immunol 2012;73:502-10.

128. Taronna A, Mazzoni E, Corallini A, Bononi I, Pietrobon S, Guerra G, Palmonari C, Borgna-Pignatti C, Comar M, Bovenzi M, Casali F, Marci R, Rezza G, Barbanti-Brodano G, Tognon M, Martini F. Serological evidence of an early seroconversion to simian virus 40 in healthy children and adolescents. PLoS One 2013;8:e61182. 
129. Mazzoni E, Tognon M, Martini F, Taronna A, Corallini A, BarbantiBrodano G, Guerra G, Carandina G, Casali F, Rezza G, Pizzo G, Valdarchi C. Simian virus 40 (SV40) antibodies in elderly subjects. $J$ Infect 2013;67:356-8.

130. Martini F, Mazzoni E, Corallini A, Taronna A, Querzoli P, Magri E, Marci R, Dolcetti R, Rezza G, Barbanti-Brodano G, Tognon M. Breast cancer and simian virus 40 infection. Epidemiology 2013;24:464-5.

131. Mazzoni E, Martini F, Corallini A, Taronna A, Barbanti-Brodano G, Querzoli P, Magri E, Rotondo JC, Dolcetti R, Vaccher E, Tognon M. Serologic investigation on undifferentiated nasopharyngeal carcinoma and simian virus 40 infection. Head Neck 2014; doi: 10.1002/hed.23879.

132. Comar M, Wong C, Tognon M, Butel JS. Neutralizing and $\mathrm{IgG}$ antibodies against simian virus 40 in healthy pregnant women in Italy. PLoS One 2014;9:e110700.

133. Borgna-Pignatti C, Mazzoni E, Felletti M, Turla G, Malaventura C, Cappellini MD, Cianciulli P, Forni GL, Corallini A, Martini F, Tognon M. Antibodies reacting with simian virus 40 mimotopes in serum samples from patients with thalassaemia major. Blood Transfus 2014;12:464-70.

134. Zur Hausen H. Papillomaviruses in the causation of human cancers-a brief historical account. Virology 2009;384:260-5.

135. Franceschi S. The IARC commitment to cancer prevention: the example of papillomavirus and cervical cancer. Recent Results Cancer Res 2005;166:277-97.

136. DiMaio D, Liao JB. Human papillomaviruses and cervical cancer. Adv Virus Res 2006;66:125-59.

137. Gjoerup O, Chang Y. Update on human polyomaviruses and cancer. Adv Cancer Res 2010;106:1-51.

138. Moody CA, Laimins LA. Human papillomavirus oncoproteins: pathways to transformation. Nat Rev Cancer 2010;10:550-60.

139. Martin D, Gutkind JS. Human tumor-associated viruses and new insights into the molecular mechanisms of cancer. Oncogene 2008;27 Suppl 2:S31-42.

140. IARC Working Group on the Evaluation of Carcinogenic Risks to Humans. Human papillomaviruses. Lyon: IARC Monogr Eval Carcinog Risks Hum. 2007. p. 1-636.

141. Zur Hausen H. Papillomaviruses causing cancer: evasion from hostcell control in early events in carcinogenesis. $J$ Natl Cancer Inst 2000;92:690-8.

142. Rodriguez AC, Schiffman M, Herrero R, Wacholder S, Hildesheim A, Castle PE, Solomon D, Burk R, Proyecto Epidemiologico Guanacaste Group. Rapid clearance of human papillomavirus and implications for clinical focus on persistent infections. J Natl Cancer Inst 2008;100:513-7.

143. Schlecht NF, Kulaga S, Robitaille J, Ferreira S, Santos M, Miyamura RA, Duarte-Franco E, Rohan TE, Ferenczy A, Villa LL, Franco EL. Persistent human papillomavirus infection as a predictor of cervical intraepithelial neoplasia. JAMA 2001;286:3106-14.

144. Munoz N, Bosch FX, de Sanjose S, Herrero R, Castellsague X, Shah $\mathrm{KV}$, Snijders PJ, Meijer CJ, International Agency for Research on Cancer Multicenter Cervical Cancer Study Group. Epidemiologic classification of human papillomavirus types associated with cervical cancer. N Engl J Med 2003;348:518-27.

145. Clifford GM, Smith JS, Plummer M, Munoz N, Franceschi S. Human papillomavirus types in invasive cervical cancer worldwide: a meta-analysis. Br J Cancer 2003;88:63-73.

146. Martini F, Iaccheri L, Martinelli M, Martinello R, Grandi E, Mollica G, Tognon M. Papilloma and polyoma DNA tumor virus sequences in female genital tumors. Cancer Invest 2004;22:697-705.

147. Hayward SD. Viral interactions with the Notch pathway. Semin Cancer Biol 2004;14:387-96.

148. Hsieh JJ, Hayward SD. Masking of the CBF1/RBPJ kappa transcriptional repression domain by Epstein-Barr virus EBNA2. Science 1995;268:560-3.
149. Liang Y, Ganem D. Lytic but not latent infection by Kaposi's sarcomaassociated herpesvirus requires host CSL protein, the mediator of Notch signaling. Proc Natl Acad Sci U S A 2003;100:8490-5.

150. Curry CL, Reed LL, Golde TE, Miele L, Nickoloff BJ, Foreman KE. Gamma secretase inhibitor blocks Notch activation and induces apoptosis in Kaposi's sarcoma tumor cells. Oncogene 2005;24:6333-44.

151. Ansieau S, Strobl LJ, Leutz A. Activation of the Notch-regulated transcription factor CBF1/RBP-Jkappa through the 13SE1A oncoprotein. Genes Dev 2001;15:380-5.

152. Rizzo P, Bocchetta M, Powers A, Foddis R, Stekala E, Pass HI, Carbone M. SV40 and the pathogenesis of mesothelioma. Semin Cancer Biol 2001;11:63-71.

153. Bocchetta M, Miele L, Pass HI, Carbone M. Notch-1 induction, a novel activity of SV40 required for growth of SV40-transformed human mesothelial cells. Oncogene 2003;22:81-9.

154. Zhang L, Qi F, Gaudino G, Strianese O, Yang H, Morris P, Pass HI, Nerurkar VR, Bocchetta M, Carbone M. Tissue tropism of SV40 transformation of human cells: role of the viral regulatory region and of cellular oncogenes. Genes Cancer 2010;1:1008-20.

155. Ali-Seyed M, Laycock N, Karanam S, Xiao W, Blair ET, Moreno CS. Cross-platform expression profiling demonstrates that SV40 small tumor antigen activates Notch, Hedgehog, and Wnt signaling in human cells. BMC Cancer 2006;6:54.

156. Wang Q, Li DC, Li ZF, Liu CX, Xiao YM, Zhang B, Li XD, Zhao J, Chen LP, Xing XM, Tang SF, Lin YC, Lai YD, Yang P, Zeng JL, Xiao Q, Zeng XW, Lin ZN, Zhuang ZX, Zhuang SM, Chen W. Upregulation of miR-27a contributes to the malignant transformation of human bronchial epithelial cells induced by SV40 small T antigen. Oncogene 2011;30:3875-86.

157. Goetz F, Tzeng YJ, Guhl E, Merker J, Graessmann M, Graessmann A. The SV40 small t-antigen prevents mammary gland differentiation and induces breast cancer formation in transgenic mice; truncated large T-antigen molecules harboring the intact $\mathrm{p} 53$ and $\mathrm{pRb}$ binding region do not have this effect. Oncogene 2001;20:2325-32.

158. Green JE, Shibata MA, Yoshidome K, Liu ML, Jorcyk C, Anver MR, Wigginton J, Wiltrout R, Shibata E, Kaczmarczyk S, Wang W, Liu ZY, Calvo A, Couldrey C. The C3(1)/SV40 T-antigen transgenic mouse model of mammary cancer: ductal epithelial cell targeting with multistage progression to carcinoma. Oncogene 2000;19:1020-7.

159. Hachana M, Trimeche M, Ziadi S, Amara K, Korbi S. Evidence for a role of the Simian Virus 40 in human breast carcinomas. Breast Cancer Res Treat 2009;113:43-58.

160. Deeb KK, Michalowska AM, Yoon CY, Krummey SM, Hoenerhoff MJ, Kavanaugh C, Li MC, Demayo FJ, Linnoila I, Deng CX, Lee EY, Medina D, Shih JH, Green JE. Identification of an integrated SV40 T/t-antigen cancer signature in aggressive human breast, prostate, and lung carcinomas with poor prognosis. Cancer Res 2007;67:8065-80.

161. Lathion S, Schaper J, Beard P, Raj K. Notch1 can contribute to viralinduced transformation of primary human keratinocytes. Cancer Res 2003;63:8687-94.

162. Daniel B, Rangarajan A, Mukherjee G, Vallikad E, Krishna S. The link between integration and expression of human papillomavirus type 16 genomes and cellular changes in the evolution of cervical intraepithelial neoplastic lesions. J Gen Virol 1997;78:1095-101.

163. Zagouras P, Stifani S, Blaumueller CM, Carcangiu ML, ArtavanisTsakonas S. Alterations in Notch signaling in neoplastic lesions of the human cervix. Proc Natl Acad Sci U S A 1995;92:6414-8.

164. Tripathi R, Rath G, Jawanjal P, Sharma S, Singhal P, Bhambhani S, Hussain S, Bharadwaj M. Clinical impact of de-regulated Notch-1 and Notch-3 in the development and progression of HPV-associated different histological subtypes of precancerous and cancerous lesions of human uterine cervix. PLoS One 2014;9:e98642.

165. Veeraraghavalu K, Pett M, Kumar RV, Nair P, Rangarajan A, Stanley MA, Krishna S. Papillomavirus-mediated neoplastic progression is 
associated with reciprocal changes in JAGGED1 and manic fringe expression linked to notch activation. J Virol 2004;78:8687-700.

166. Kuncharin Y, Sangphech N, Kueanjinda P, Bhattarakosol P, Palaga T. MAML1 regulates cell viability via the NF-kappaB pathway in cervical cancer cell lines. Exp Cell Res 2011;317:1830-40.

167. Rangarajan A, Syal R, Selvarajah S, Chakrabarti O, Sarin A, Krishna S. Activated Notch1 signaling cooperates with papillomavirus oncogenes in transformation and generates resistance to apoptosis on matrix withdrawal through PKB/ Akt. Virology 2001;286:23-30.

168. Nair P, Somasundaram K, Krishna S. Activated Notch1 inhibits p53-induced apoptosis and sustains transformation by human papillomavirus type $16 \mathrm{E} 6$ and E7 oncogenes through a PI3K-PKB/ Akt-dependent pathway. J Virol 2003;77:7106-12.

169. Veeraraghavalu K, Subbaiah VK, Srivastava S, Chakrabarti O, Syal R, Krishna S. Complementation of human papillomavirus type 16 E6 and E7 by Jagged1-specific Notch1-phosphatidylinositol 3-kinase signaling involves pleiotropic oncogenic functions independent of CBF1;Su(H);Lag-1 activation. J Virol 2005;79:7889-98.

170. Ramdass B, Maliekal TT, Lakshmi S, Rehman M, Rema P, Nair P, Mukherjee G, Reddy BK, Krishna S, Radhakrishna Pillai M. Coexpression of Notch1 and NF-kappaB signaling pathway components in human cervical cancer progression. Gynecol Oncol 2007;104:352-61.

171. Weijzen S, Zlobin A, Braid M, Miele L, Kast WM. HPV16 E6 and E7 oncoproteins regulate Notch-1 expression and cooperate to induce transformation. J Cell Physiol 2003;194:356-62.

172. Vliet-Gregg PA, Hamilton JR, Katzenellenbogen RA. NFX1-123 and human papillomavirus 16E6 increase Notch expression in keratinocytes. J Virol 2013;87:13741-50.

173. Vliet-Gregg PA, Hamilton JR, Katzenellenbogen RA. Human papillomavirus 16E6 and NFX1-123 potentiate Notch signaling and differentiation without activating cellular arrest. Virology 2015;478:50-60.

174. Rangarajan A, Talora C, Okuyama R, Nicolas M, Mammucari C, Oh H, Aster JC, Krishna S, Metzger D, Chambon P, Miele L, Aguet M, Radtke F, Dotto GP. Notch signaling is a direct determinant of keratinocyte growth arrest and entry into differentiation. EMBO J 2001;20:3427-36.

175. Koh LF, Ng BK, Bertrand J, Thierry F. Transcriptional control of late differentiation in human keratinocytes by TAp63 and Notch. Exp Dermatol 2015;24:754-60.

176. Kagawa S, Natsuizaka M, Whelan KA, Facompre N, Naganuma S, Ohashi S, Kinugasa H, Egloff AM, Basu D, Gimotty PA, Klein-Szanto AJ, Bass AJ, Wong KK, Diehl JA, Rustgi AK, Nakagawa H. Cellular senescence checkpoint function determines differential Notch1dependent oncogenic and tumor-suppressor activities. Oncogene 2015;34:2347-59.

177. Talora C, Sgroi DC, Crum CP, Dotto GP. Specific down-modulation of Notch1 signaling in cervical cancer cells is required for sustained HPV-E6/E7 expression and late steps of malignant transformation.
Genes Dev 2002;16:2252-63.

178. Tan MJ, White EA, Sowa ME, Harper JW, Aster JC, Howley PM. Cutaneous beta-human papillomavirus E6 proteins bind Mastermindlike coactivators and repress Notch signaling. Proc Natl Acad Sci U S A 2012;109:E1473-80

179. Rozenblatt-Rosen O, Deo RC, Padi M, Adelmant G, Calderwood MA, Rolland T, Grace M, Dricot A, Askenazi M, Tavares M, Pevzner SJ, Abderazzaq F, Byrdsong D, Carvunis AR, Chen AA, Cheng J, Correll M, Duarte M, Fan C, Feltkamp MC, Ficarro SB, Franchi R, Garg BK, Gulbahce N, Hao T, Holthaus AM, James R, Korkhin A, Litovchick L, Mar JC, Pak TR, Rabello S, Rubio R, Shen Y, Singh S, Spangle JM, Tasan M, Wanamaker S, Webber JT, RoeckleinCanfield J, Johannsen E, Barabasi AL, Beroukhim R, Kieff E, Cusick ME, Hill DE, Munger K, Marto JA, Quackenbush J, Roth FP, DeCaprio JA, Vidal M. Interpreting cancer genomes using systematic host network perturbations by tumour virus proteins. Nature 2012;487:491-5.

180. Brimer N, Lyons C, Wallberg AE, Vande Pol SB. Cutaneous papillomavirus E6 oncoproteins associate with MAML1 to repress transactivation and NOTCH signaling. Oncogene 2012;31:4639-46.

181. Meyers JM, Spangle JM, Munger K. The human papillomavirus type 8 E6 protein interferes with NOTCH activation during keratinocyte differentiation. J Virol 2013;87:4762-7.

182. Song LL, Peng Y, Yun J, Rizzo P, Chaturvedi V, Weijzen S, Kast WM, Stone PJ, Santos L, Loredo A, Lendahl U, Sonenshein G, Osborne B, Qin JZ, Pannuti A, Nickoloff BJ, Miele L. Notch-1 associates with IKKalpha and regulates IKK activity in cervical cancer cells. Oncogene 2008;27:5833-44.

183. Henken FE, De-Castro Arce J, Rosl F, Bosch L, Meijer CJ, Snijders PJ, Steenbergen RD. The functional role of Notch signaling in HPV-mediated transformation is dose-dependent and linked to AP-1 alterations. Cell Oncol (Dordr) 2012;35:77-84.

184. Agrawal N, Frederick MJ, Pickering CR, Bettegowda C, Chang K, Li RJ, Fakhry C, Xie TX, Zhang J, Wang J, Zhang N, ElNaggar AK, Jasser SA, Weinstein JN, Trevino L, Drummond JA, Muzny DM, Wu Y, Wood LD, Hruban RH, Westra WH, Koch WM, Califano JA, Gibbs RA, Sidransky D, Vogelstein B, Velculescu VE, Papadopoulos N, Wheeler DA, Kinzler KW, Myers JN. Exome sequencing of head and neck squamous cell carcinoma reveals inactivating mutations in NOTCH1. Science 2011;333:1154-7.

185. Seiwert TY, Zuo Z, Keck MK, Khattri A, Pedamallu CS, Stricker T, Brown C, Pugh TJ, Stojanov P, Cho J, Lawrence MS, Getz G, Bragelmann J, DeBoer R, Weichselbaum RR, Langerman A, Portugal L, Blair E, Stenson K, Lingen MW, Cohen EE, Vokes EE, White KP, Hammerman PS. Integrative and comparative genomic analysis of HPV-positive and HPV-negative head and neck squamous cell carcinomas. Clin Cancer Res 2015;21:632-41. 